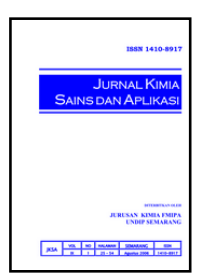

\title{
Pengaruh Penambahan Polivinil Alkohol pada Biomassa Tongkol Jagung-Bulu Ayam sebagai Adsorben Campuran Ion Logam Tembaga dan Kromium
}

\author{
Dahlia Nurmalasari ${ }^{a}$, Rum Hastuti ${ }^{\mathrm{a}^{*}}$, Didik Setiyo Widodo ${ }^{\mathrm{a}}$ \\ a Analytical Chemistry Laboratory, Chemistry Department, Faculty of Sciences and Mathematics, Diponegoro University, Jalan Prof. \\ Soedarto, Tembalang, Semarang \\ * Corresponding author: rum.hastuti@live.undip.ac.id
}

\begin{tabular}{l} 
Article Info \\
\hline Keywords: \\
adsorption, \\
corncob, chicken \\
feather, alcohol \\
polyvinyl, copper, \\
chromium
\end{tabular}

Kata Kunci: adsorsi, tongkol jagung, bulu ayam, polivinil alkohol, tembaga, kromium

\begin{abstract}
Research on the effect of addition of polyvinyl alcohol on the biomass of corncobchicken feathers as an adsorbent of copper and chromium metal ion mixtures has been performed. The aims of this study were to obtain adsorbent made from corncob-chicken feather $\left(A_{1}\right)$, polyvinyl alcohol modified corncob-chicken feather adsorbent $\left(A_{2}\right)$ and character of the adsorbent produced and to determine the adsorption capacity of the adsorbent. The result of FTIR characterization showed that the addition of $\mathrm{OH}$ group on the adsorbent $\left(A_{2}\right)$. While BET results showed that the adsorbent $\left(A_{2}\right)$ decreased surface area and total pore volume by $39.83 \%$ and $21.89 \%$, while the average pore size increased by $29.54 \%$. The adsorbent capacity of $\mathrm{A}_{1}$ and $\mathrm{A}_{2}$ on the absorption of the best copper and chromium metal ion mixture at the best contact time was at 120 and 90 minutes with the best concentration (1: 1) of $30 \mathrm{ppm}$. The maximum adsorption capacity by $\mathrm{A}_{1}$ or $\mathrm{A}_{2}$ adsorbents for copper metal ions is $2.02 \times 10^{-3} \mathrm{~mol} \mathrm{~g}^{-1}$ and $2.49 \times 10^{-3} \mathrm{~mol} \mathrm{~g}^{-1}$, respectively, while for chromium metal ions is $1.49 \times 10^{-3} \mathrm{~mol} \mathrm{~g}^{-1}$ and $1.63 \times 10^{-3} \mathrm{~mol} \mathrm{~g}^{-1}$.
\end{abstract}

\section{Abstrak}

Penelitian tentang pengaruh penambahan polivinil alkohol pada biomassa dari (tongkol jagung)-(bulu ayam) sebagai adsorben campuran ion logam tembaga dan kromium telah dilakukan. Tujuan penelitian ini adalah untuk mendapatkan adsorben (tongkol jagung)-(bulu ayam) ( $\left.\mathrm{A}_{1}\right)$, adsorben (tongkol jagung)-(bulu ayam) termodifikasi polivinil alkohol $\left(\mathrm{A}_{2}\right)$ dan karakter dari adsorben yang dihasilkan serta menentukan kapasitas adsorpsi dari adsorben. Hasil karakterisasi FTIR menunjukkan bahwa adanya penambahan gugus $\mathrm{OH}$ pada adsorben $\left(\mathrm{A}_{2}\right)$. Sementara hasil BET menunjukkan bahwa adsorben $\left(\mathrm{A}_{2}\right)$ mengalami penurunan luas permukaan dan total volume pori sebesar $39,83 \%$ dan $21,89 \%$, sedangkan rata-rata ukuran pori mengalami kenaikan sebesar $29,54 \%$. Kemampuan adsorben $A_{1}$ maupun $A_{2}$ terhadap penyerapan campuran ion logam tembaga dan kromium waktu kontak terbaik adalah pada 120 dan 90 menit dengan konsentrasi terbaik (1:1) yaitu $30 \mathrm{ppm}$. Kapasitas adsorpsi maksimum oleh adsorben $\mathrm{A}_{1}$ maupun $\mathrm{A}_{2}$ untuk ion logam tembaga masing-masing sebesar 2,02.10-3 mol g-1 dan 2,49.10-3 mol g-1, sedangkan untuk ion logam kromium sebesar 1,49.10-3 mol g-1 dan 1,63.10-3 mol g-1.

\section{Pendahuluan}

Logam berat merupakan elemen yang berbahaya di permukaan bumi. Logam berat yang ada di dalam limbah contohnya adalah kromium dan tembaga. Bila unsur logam kromium (Cr) masuk dalam tubuh, meski dalam jumlah agak berlebihan biasanya tidaklah menimbulkan pengaruh yang buruk terhadap tubuh, 
karena unsur kromium (Cr) dalam bentuk ion $\mathrm{Cr}$ (III) diperlukan dalam metabolisme gula pada tubuh manusia. Kromium(VI) yang biasa disebut kromat merupakan unsur yang sangat toksik. Penyebaran kromium(VI) biasanya terdapat pada garam kromat seperti $\mathrm{NA}_{2} \mathrm{CrO}_{4}$. Unsur logam berat tembaga $(\mathrm{Cu})$, bila masuk ke dalam tubuh dalam jumlah berlebihan akan menimbulkan pengaruh-pengaruh buruk terhadap fungsi fisiologis tubuh [1].

Salah satu cara penanganan terhadap limbah sebelum limbah dibuang ke lingkungan adalah adsorpsi. Adsorpsi merupakan fenomena yang melibatkan interaksi fisik, kimia dan gaya elektrostatik antara adsorbat dengan adsorben pada permukaan adsorben. Gaya tarik-menarik suatu padatan dibedakan menjadi dua jenis gaya yaitu gaya fisika dan gaya kimia yang masing-masing menghasilkan adsorpsi fisika (physisorption) dan adsorpsi kimia (chemisorption).

Penelitian-penelitian sebelumnya telah banyak dikembangkan teknologi aplikasi adsorpsi, yakni menggunakan bahan biomaterial untuk menurunkan kadar logam berat dari badan air (biosorpsi). Ramya $d k k$. [2] telah berhasil melakukan adsorpsi logam $\mathrm{Cu}$ dan $\mathrm{Ni}$ dengan adsorben crosslink chitosan-g-acrylonitrile. Chowdhury dan Saha [3] telah berhasil melakukan adsorpsi zat warna methylene blue dan ion logam $\mathrm{Pb}^{2+}$ dalam air limbah dengan menggunakan biomassa bulu ayam. Penelitian lain dilakukan oleh Leyva-Ramos $d k k$. [4] yang telah berhasil melakukan adsorpsi $\mathrm{Zn}, \mathrm{Cr}$, Ni dan Cd dalam air limbah dengan menggunakan tongkol jagung dan tongkol jagung modifikasi dengan asam sitrat.

Sebagai limbah hasil pertanian tongkol jagung menurut Lorenz dan Kulp [5] mempunyai kandungan selulosa $(41 \%)$ dan hemiselulosa $(36 \%)$ yang cukup tinggi. Tingginya persentase selulosa yang mengandung gugus hidroksil $(\mathrm{OH})$ pada tongkol jagung yang belum banyak dimanfaatkan, dapat dipakai sebagai alternatif bahan baku pembuatan adsorben. Bulu ayam merupakan permasalahan lain dari limbah hasil peternakan yang mengandung protein serat atau keratin yaitu protein kasar $(80,00 \%)$, lemak kasar $(7,79 \%)$ dan serat kasar $(0,88 \%)[6]$. Keratin mengandung gugus-gugus $\mathrm{N}-\mathrm{H}$, $\mathrm{C}=\mathrm{O}, \mathrm{O}-\mathrm{H}, \mathrm{COOH}$ dan $\mathrm{S}-\mathrm{H}[7]$.

Pada penelitian ini pemanfaatan tongkol jagungbulu ayam dengan modifikasi polivinil alkohol (PVA) sebagai adsorben diharapkan dapat meningkatkan karakteristik adsorben dalam kemampuan adsorpsi, permukaan pori-pori dan efektifitas adsorpsi untuk mengatasi ion logam campuran tembaga dan kromium dalam limbah cair industri logam.

\section{Metode Penelitian}

\section{Alat dan Bahan}

Alat-alat yang digunakan dalam penelitian ini adalah timbangan elektrik, penyaring Buchner, kertas saring, penggilingan bulu ayam, penangas, alat-alat gelas, magnetic stirrer, spektrofotometer serapan atom (AAS), spektrofotometer FTIR, BET (Brunauer Emmett
Teller). Bahan-bahan yang digunakan adalah bulu ayam, tongkol jagung, polivinil alkohol, asam asetat (p.a), $\mathrm{NaOH}$ (p,a), dietil eter, gluteraldehid, $\mathrm{CuSO}_{4 \cdot 5} \mathrm{H}_{2} \mathrm{O}$ (p.a), $\mathrm{K}_{2} \mathrm{Cr}_{2} \mathrm{O}_{7}$ (p.a), aqubides.

\section{Preparasi Adsorben Tongkol Jagung}

Tongkol Jagung dicuci dan dikeringkan kemudian dihaluskan dan disaring hingga didapatkan adsorben serbuk tongkol jagung. Adsorben serbuk tongkol jagung yang didapatkan dikarakterisasi dengan FTIR.

\section{Preparasi Adsorben Bulu Ayam}

Bulu ayam dicuci dengan air dan deterjen, kemudian dijemur sampai kering dan hilang baunya. Setelah kering, bulu ayam tersebut dipotong kecil-kecil sehingga diperoleh adsorben yang halus. Adsorben yang sudah halus direndam dengan dietileter selama 24 jam kemudian disaring dengan menggunakan corong Buchner. Residu yang didapat dikeringkan dengan oven sehingga didapatkan adsorben bulu ayam, kemudian adsorben bulu ayam dikarakterisasi dengan FTIR.

\section{Pembuatan Adsorben Tongkol Jagung-Bulu Ayam $\left(A_{1}\right)$}

Adsorben bulu ayam ditambahkan dalam larutan asam asetat $1 \%$. Kemudian dicampur dan diaduk hingga homogen dengan magnetic stirrer. Serbuk tongkol jagung kemudian direndam dalam larutan asam asetat dan bulu ayam yang sudah homogen selama 30 menit. Setelah itu disaring dan direndam dalam larutan $\mathrm{NaOH} 1 \mathrm{M}$ selama 24 jam. Kemudian, disaring dan direndam kembali selama 24 jam dalam larutan pengikat silang glutaraldehid $0,02 \%(\mathrm{v} / \mathrm{v})$.

\section{Pembuatan Adsorben Tongkol Jagung-Bulu Ayam Modifikasi PVA $\left(\mathrm{A}_{2}\right)$}

Larutan asam asetat $1 \%$ ditambahkan PVA sedikit demi sedikit dengan pemanasan hingga homogen. Kemudian dicampur dengan adsorben bulu ayam dan diaduk dengan magnetic stirrer. Serbuk tongkol jagung kemudian direndam dalam larutan asam asetat-bulu ayam-PVA yang sudah homogen selama 30 menit. Setelah itu disaring dan direndam dalam larutan $\mathrm{NaOH}$ 1 M selama 24 jam. Kemudian, disaring dan direndam kembali selama 24 jam dalam larutan pengikat silang glutaraldehid $0,02 \%(\mathrm{v} / \mathrm{v})$.

Optimasi Penyerapan Campuran Ion Logam Tembaga dan Kromium pada Adsorben $\mathrm{A}_{1}$ dan Adsorben $\mathrm{A}_{2}$

\section{Variabel Waktu Kontak}

Sebanyak 0,5 gram adsorben $A_{1}$ dan adsorben $A_{2}$ direndam didalam $50 \mathrm{ml}$ larutan sampel campuran logam (1:1) 10 ppm. Waktu kontak diatur dengan variasi waktu 30-150 menit dengan interval 30 menit. Larutan disaring dan filtrat dianalisis dengan AAS.

\section{Variabel Konsentrasi}

Sebanyak 0,5 gram adsorben $A_{1}$ dan adsorben $A_{2}$ masing-masing direndam dalam larutan sampel campuran logam dengan variasi konsentrasi (1:1) 10, 20, 30, 40, dan 50 ppm sampai batas waktu serapan optimum dan $\mathrm{pH}$ 5. Filtratnya dianalisis dengan menggunakan AAS. 


\section{Hasil Dan Pembahasan}

\section{Karakterisasi Adsorben $\mathrm{A}_{1}$ dan $\mathrm{A}_{2}$ Menggunakan FTIR}

Analisis dengan menggunakan Fourier Transform Infrared Spectroscopy (FTIR) bertujuan untuk menentukan gugus fungsi yang ada pada adsorben tongkol jagung, adsorben bulu ayam, adsorben tongkol jagung-bulu ayam $\left(\mathrm{A}_{1}\right)$ dan adsorben tongkol jagungbulu ayam modifikasi PVA $\left(\mathrm{A}_{2}\right)$. Hasil analisis spektra FTIR dari masing-masing adsorben disajikan pada gambar 1, 2, 3, dan 4 .

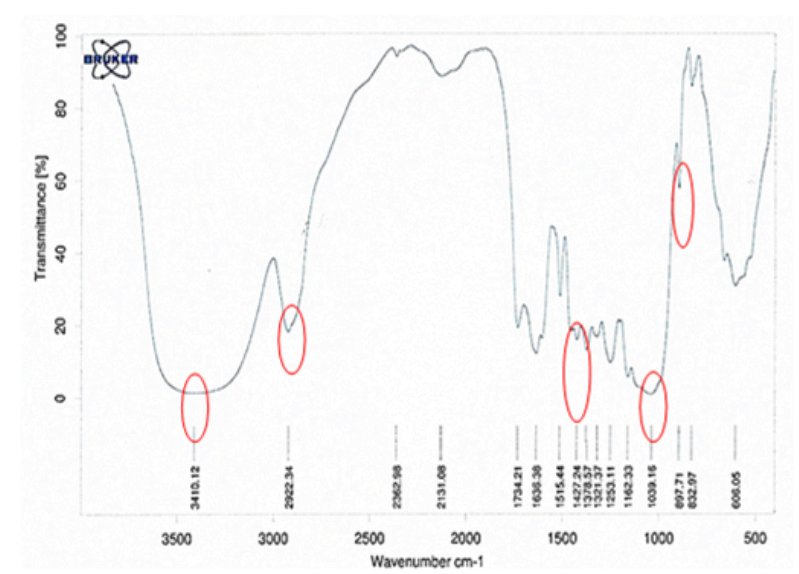

Gambar 1. Spektra FTIR Adsorben Tongkol Jagung

Gambar 1 menunjukkan bahwa pada spektra serapan daerah $3410 \mathrm{~cm}^{-1}$ menunjukkan rentang vibrasi ulur $\mathrm{OH}$, vibrasi $\mathrm{C}-\mathrm{H}$ ulur muncul pada serapan 2922 $\mathrm{cm}^{-1}$, vibrasi C-O ulur muncul pada serapan $1039 \mathrm{~cm}^{-1}$, vibrasi $\mathrm{CH}_{2}$ muncul pada serapan $1427 \mathrm{~cm}^{-1}$ dan ikatan $\beta$-glikosida muncul pada serapan $897 \mathrm{~cm}^{-1}$ [8]. Berdasarkan hasil spektra FTIR dapat disimpulkan bahwa di dalam tongkol jagung terdapat gugus-gugus selulosa.

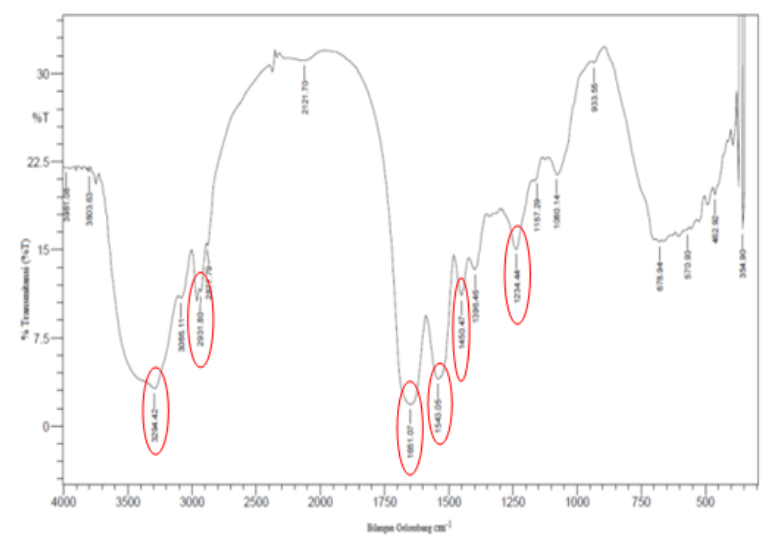

Gambar 2. Spektra FTIR Adsorben Bulu Ayam

Gambar 2 pada spektra serapan daerah $3294 \mathrm{~cm}^{-1}$ menunjukan rentang vibrasi ulur $\mathrm{O}-\mathrm{H}$ simetris $\mathrm{N}-\mathrm{H}$ diperkuat dengan adanya $\mathrm{N}-\mathrm{H}$ tekuk yang menyerap dekat pada serapan $1543 \mathrm{~cm}^{-1}$. Vibrasi ulur C-H muncul pada serapan $2931 \mathrm{~cm}^{-1}$ yang diperkuat $\mathrm{C}-\mathrm{H}$ tekuk pada serapan $1450 \mathrm{~cm}^{-1}$. Adanya pita serapan pada daerah serapan $1651 \mathrm{~cm}^{-1}$ yang diidentifikasi sebagai gugus $\mathrm{C}=\mathrm{O}$, pada serapan $1234 \mathrm{~cm}^{-1}$ menandai vibrasi ulur rentangan dari C-O asam karboksilat [9]. Berdasarkan hasil spektra
FTIR dapat disimpulkan bahwa di dalam bulu ayam terdapat gugus-gugus keratin yaitu $\mathrm{N}-\mathrm{H}, \mathrm{C}=\mathrm{O}, \mathrm{O}-\mathrm{H}$, dan $\mathrm{COOH}[7]$.

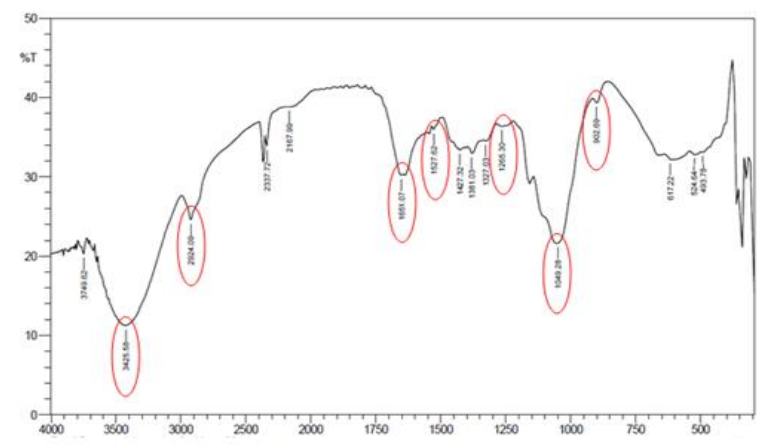

Gambar 3. Spektra FTIR Adsorben Tongkol JagungBulu Ayam $\left(\mathrm{A}_{1}\right)$



Gambar 4. Spektra FTIR Adsorben Tongkol JagungBulu Ayam Modifikasi PVA $\left(\mathrm{A}_{2}\right)$

Gambar 3 dan 4 dapat disimpulkan bahwa spektra FTIR adsorben $A_{1}$ dan $A_{2}$ masih mengandung gugus aktif yang terdapat pada selulosa dari tongkol jagung dan keratin dari bulu ayam seperti gambar 1 dan 2. Hal ini dikarenakan PVA mempunyai gugus yang sama dengan selulosa yaitu gugus $\mathrm{OH}$ sehingga tidak terlihat adanya perubahan bilangan gelombang yang menunjukkan gugus baru pada adsorben.

Karakterisasi Adsorben $\mathrm{A}_{1}$ dan $\mathrm{A}_{2}$ Menggunakan BET

Analisa dengan menggunakan BET (Brunauer, Emmet, Teller) bertujuan untuk mengetahui luas permukaan, rata-rata pori, dan total volume pori adsorben. Karakterisasi adsorben $\left(\mathrm{A}_{1}\right)$ dan adsorben $\left(\mathrm{A}_{2}\right)$ dengan BET disajikan pada tabel 1.

Tabel 1: Data Hasil Uji GSA

\begin{tabular}{ccc}
\hline \multirow{2}{*}{ Hasil } & \multicolumn{2}{c}{ Tongkol Jagung-Bulu Ayam } \\
\cline { 2 - 3 } & Adsorben $\mathrm{A}_{1}$ & Adsorben $\mathrm{A}_{2}$ \\
\hline Luas Permukaan $\left(\mathrm{m}^{2} / \mathrm{g}\right)$ & 0.836 & 0.503 \\
Total Volume Pori $(\mathrm{cc} / \mathrm{g})$ & $1.23 \times 10^{-3}$ & $0,9608 \times 10^{-3}$ \\
Rata-rata Pori $(\AA)$ & 59.008 & 76.441 \\
\hline
\end{tabular}

Berdasarkan data pada tabel 1 terlihat pada adsorben $\mathrm{A}_{2}$ mengalami penurunan luas permukaan dan total volume pori sebesar $39,83 \%$ dan $21,89 \%$, sedangkan rata-rata pori mengalami peningkatan sebesar 29,54\%. Hal ini terjadi karena adanya 
penambahan PVA yang berperan selain sebagai penyumbang gugus $\mathrm{OH}$ juga dapat berperan sebagai perekat antara tongkol jagung-bulu ayam dan porogenitas. Dampak pertambahan ukuran pori adalah akan mempengaruhi kemampuan adsorben dalam melakukan penyerapan terhadap ion logam campuran tembaga dan kromium sehingga hasil yang diperoleh menjadi maksimal.

Optimasi Penyerapan Campuran Ion Logam Tembaga dan Kromium oleh Adsorben $\mathrm{A}_{1}$ dan $\mathrm{A}_{2}$

\section{Variabel Waktu Kontak}

Kondisi terbaik untuk waktu kontak dilakukan pada variasi waktu antara 30 sampai 150 menit dengan selang waktu 30 menit yang bertujuan untuk mendapatkan waktu kontak terbaik pada penyerapan campuran ion logam tembaga dan kromium oleh adsorben $\mathrm{A}_{1}$ maupun adsorben $A_{2}$. Salah satu variabel yang mempengaruhi proses penyerapan adalah waktu kontak antara adsorben dengan adsorbat. Menurut Cheremisinoff dan Ellerbusch [10], waktu kontak antara ion logam dengan adsorben sangat mempengaruhi kemampuan serap. Semakin lama waktu kontak maka penyerapan juga akan meningkat sampai pada waktu tertentu akan mencapai maksimum dan setelah itu akan turun kembali [11]. Pengaruh waktu kontak terhadap adsorpsi ion logam campuran tembaga dan kromium oleh adsorben $\mathrm{A}_{1}$ dan adsorben $\mathrm{A}_{2}$ dilihat pada gambar 5 dan 6 .

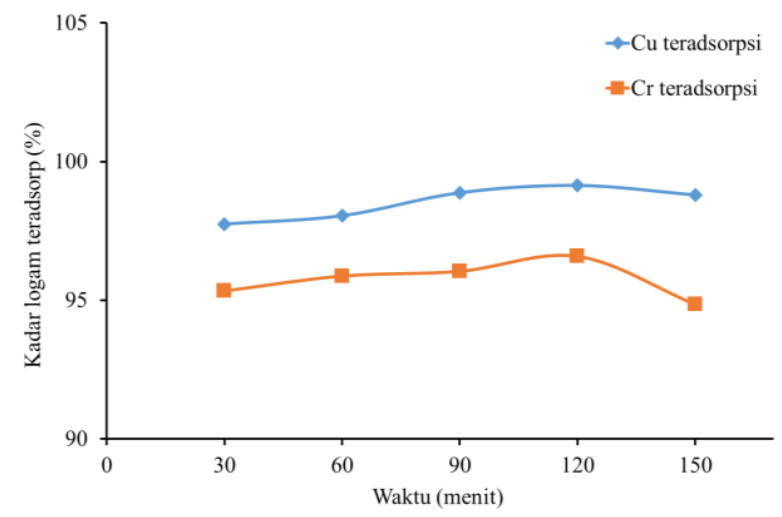

Gambar 5. Grafik Hubungan antara waktu dengan \% kadar logam teradsorps oleh adsorben $A_{1}$

Pada gambar 5 menunjukkan bahwa adsorpsi ion logam tembaga dan kromium oleh adsorben $\mathrm{A}_{1}$ mengalami penyerapan terbaik yang sama yaitu pada waktu 120 menit setelah itu pada waktu 150 menit mengalami penurunan adsorpsi. Sedangkan pada gambar 6 untuk adsorben $A_{2}$ waktu kontak terbaik yang diperoleh dari ion logam tembaga dan kromium yaitu pada waktu 90 menit, setelah itu pada waktu 120-150 menit mengalami penurunan adsorpsi. Hal ini dikarenakan waktu kontak antara adsorben dan adsorbat yang melebihi waktu kontak terbaik dapat menyebabkan desorpsi. Desorpsi merupakan pelepasan adsorbat dari permukaan adsorben. Fenomena ini terjadi akibat permukaan adsorben telah jenuh, sehingga molekul adsorbat yang telah terjerap kembali kedalam larutan [12].

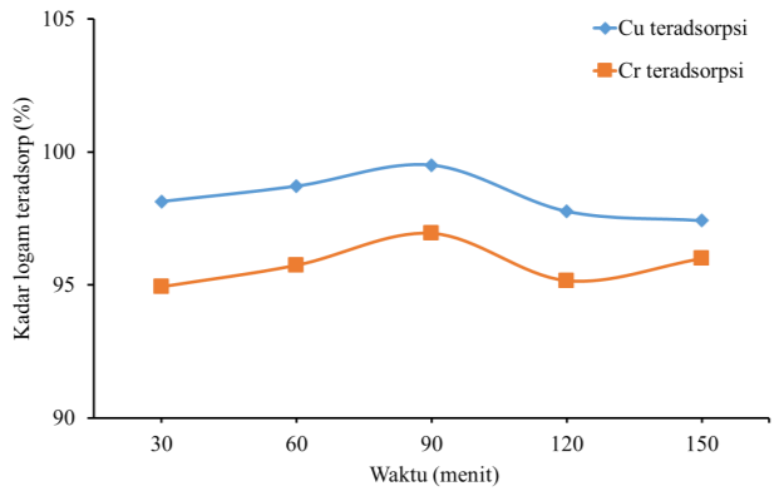

Gambar 6. Grafik Hubungan antara waktu dengan \% kadar logam teradsorps oleh adsorben $\mathrm{A}_{2}$

Waktu adsorbsi terbaik untuk adsorben $\mathrm{A}_{2}$ lebih singkat jika dibandingkan dengan adsorben $A_{1}$. Waktu adsorpsi yang lebih singkat menunjukkan penyerapan yang terjadi lebih cepat, ini disebabkan karena adanya penambahan gusus aktif $\mathrm{OH}$ dan membesarnya ukuran pori adsorben oleh PVA.

\section{Variabel Konsentrasi}

Adsorpsi ion logam tembaga dan kromium pada variasi konsentrasi dilakukan pada kondisi waktu kontak terbaik untuk adsorben $\mathrm{A}_{1}$ yaitu 120 menit sedangkan waktu kontak terbaik 90 menit untuk adsroben $\mathrm{A}_{2}$ dan $\mathrm{pH}$ yang telah ditetapkan yaitu pada $\mathrm{pH}$ 5. Semakin besar konsentrasi larutan campuran ion logam tembaga dan kromium maka kemampuan adsorpsi adsorben $A_{1}$ dan adsorben $A_{2}$ juga semakin meningkat.

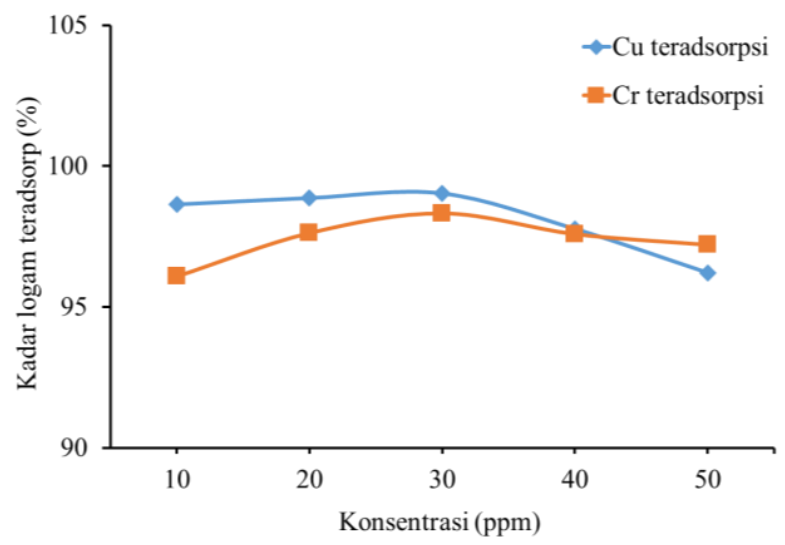

Gambar 7. Grafik hubungan antara konsentrasi dengan $\%$ kadar logam teradsorps oleh adsorben $\mathrm{A}_{1}$

Terlihat pada gambar 7 dan 8, \% kadar ion logam tembaga dan kromium oleh adsorben $\mathrm{A}_{1}$ maupun adsorben $\mathrm{A}_{2}$ mencapai konsentrasi terbaik yang sama yaitu pada $30 \mathrm{ppm}$. Hal ini disebabkan dengan semakin besar konsentrasi larutan logam maka akan semakin banyak molekul ion logam yang berinteraksi dengan adsorben sehingga pada suatu saat akan mencapai batas optimum adsorpsi. 


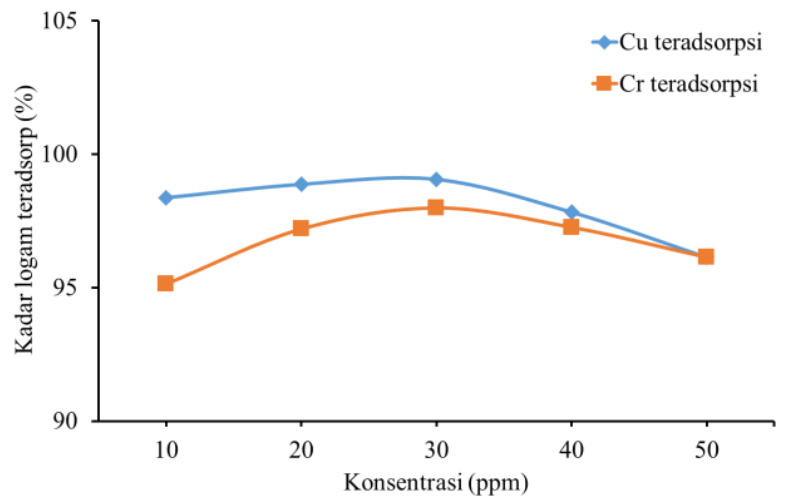

Gambar 8 Grafik hubungan antara konsentrasi dengan $\%$ kadar logam teradsorps oleh adsorben $\mathrm{A}_{2}$

Kapasitas adsorpsi maksimum masing-masing ion logam tembaga dan kromium oleh adsorben $A_{1}$ dan $A_{2}$ dapat diinterpretasikan data yang dihasilkan dengan isotherm adsorpsi Langmuir. Hasil perhitungan dari data tersebut diperoleh kapasitas adsorpsi maksimum oleh adsorben $A_{1}$ untuk ion logam tembaga dan kromium sebesar 2,02.10 $\mathrm{mol} \mathrm{g}^{-1}$ dan $1,49.10^{-3} \mathrm{~mol} \mathrm{~g}^{-1}$. Sedangkan hasil perhitungan data kapasitas adsorpsi maksimum ion logam tembaga dan kromium oleh adsorben $\mathrm{A}_{2}$ sebesar $2,49.10^{-3} \mathrm{~mol} \mathrm{~g}^{-1}$ dan $1,63.10^{-3} \mathrm{~mol}$ $\mathrm{g}^{-1}$.

Dapat disimpulkan bahwa hasil perhitungan kapasitas adsorpsi maksimum tembaga dan kromium oleh adsorben $A_{2}$ lebih besar dibandingkan adsorben $A_{1}$. Hal ini dikarenakan adsorben $\mathrm{A}_{2}$ memiliki gugus yang bermuatan negatif lebih banyak sehingga logam yang bermuatan positif dapat berinteraksi dengan adsorben baik secara fisis maupun kimia.

Oscik [13] menyatakan bahwa jenis interaksi antara logam dan adsorben dapat dilakukan dengan menghitung energi adsorpsi berdasarkan rumus :

$$
E_{\mathrm{ads}}=-\Delta \mathrm{G}_{\mathrm{ads}}^{\mathrm{o}}=\mathrm{RT} \ln \mathrm{K}
$$

$\mathrm{K}$ adalah tetapan kesetimbangan adsorpsi yang diperoleh dari persamaan Langmuir dan energi total adsorpsi sama dengan energi bebas Gibbs. Dari perhitungan energi adsorpsi diperoleh data yg ditunjukan pada tabel 2.

Tabel 2: Energi Adsorpsi Ion Logam Tembaga dan Kromium oleh Adsorben $\mathrm{A}_{1}$ dan $\mathrm{A}_{2}$

\begin{tabular}{cccc}
\hline $\begin{array}{c}\text { Adsorben } \\
\text { /Ion logam }\end{array}$ & $\begin{array}{c}\text { Konstanta } \\
\text { kesetimbangan } \\
\text { adsorpsi (K) }\end{array}$ & $\begin{array}{c}\text { Energi } \\
\text { Adsorpsi } \\
\left(\mathrm{kJ} \mathrm{mol}^{-1}\right)\end{array}$ \\
\hline \multirow{2}{*}{$\mathrm{A}_{1} \quad \mathrm{Cu}$} & 43874,85 & 26,66 \\
& $\mathrm{Cr}$ & 19120,45 & 24,59 \\
$\mathrm{~A}_{2}$ & $\mathrm{Cu}$ & 31771,44 & 25,85 \\
& $\mathrm{Cr}$ & 14537,84 & 23,90 \\
\hline
\end{tabular}

Tabel 2 menunjukan bahwa adsorpsi campuran ion logam tembaga dan kromium, baik oleh adsorben $\mathrm{A}_{1}$ maupun $\mathrm{A}_{2}$ dikategorikan sebagai adsorpsi secara kimia (kemisorpsi) yang melibatkan ikatan langsung antara adsorbat dengan gugus aktif adsorben. Adsorpsi kimia (kemisorpsi) terjadi apabila energi adsorpsi lebih dari
$20,92 \mathrm{~kJ} \mathrm{~mol}^{-1}[14]$. Akan tetapi untuk adsorpsi ion logam tembaga dan kromium kemungkinan terjadi tidak hanya secara kimia saja tetapi juga secara fisik, hanya saja interaksi kimia lebih dominan dibandingkan interaksi secara fisik. Hal ini dimungkinkan karena selain adsorpsi secara kimia terdapat juga kontribusi adsorpsi secara fisik, sebab pada kenyataannya hampir tidak semua adsorpsi hanya mengikuti satu jalur mekanisme saja [15].

Setelah dilakukan penyerapan oleh adsorben $\mathrm{A}_{2}$ dan dikarakterisasi dengan menggunakan spektroskopi FTIR. Berdasarkan hasil spektra adsorben setelah mengadsorpsi campuran ion logam tembaga dan kromium terjadi penambahan gugus yang berasal dari logam yang diserap. Hal ini ditunjukkan dengan adanya pergeseran bilangan gelombang pada gugus spektra FTIR adsorben $\mathrm{A}_{2}$ setelah adsorpsi yaitu pada $570 \mathrm{~cm}^{-1}$ menunjukan serapan $\mathrm{Cu}-\mathrm{O}$ [16], pada bilangan gelombang $439 \mathrm{~cm}^{-1}$ menunjukan serapan $\mathrm{Cu}-\mathrm{N}$ [17] dan pada $354 \mathrm{~cm}^{-1}$ menunjukan serapan $\mathrm{Cr}-\mathrm{O}$.

Berikut hasil FTIR adsorben $\mathrm{A}_{2}$ setelah mengadsorpsi campuran ion logam tembaga dan kromium dapat dilihat pada gambar 9.

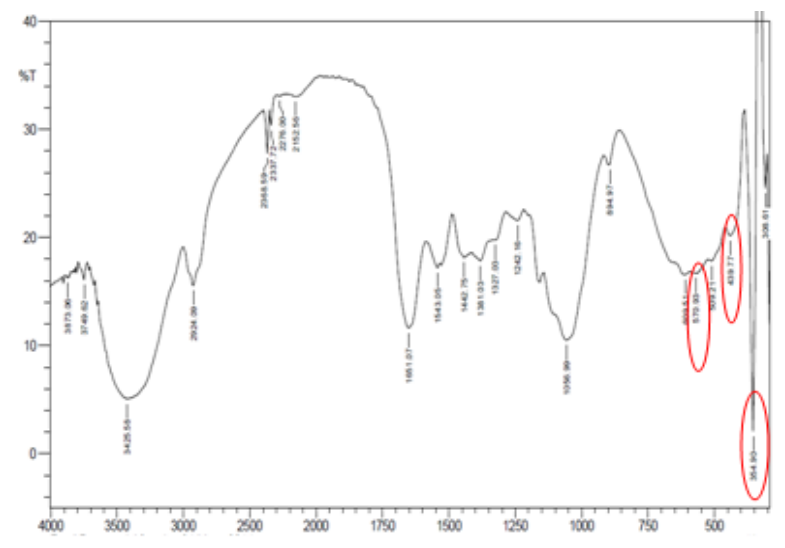

Gambar 9. Spektra FTIR Adsorben $A_{2}$ setelah mengadsorpsi campuran ion logam tembaga dan kromium

\section{Kesimpulan}

Berdasarkan hasil penelitian dapat disimpulkan bahwa adsorben $\mathrm{A}_{2}$ dapat digunakan sebagai adsorben dalam penyerapan ion logam. Hasil karakterisasi FTIR menunjukkan adanya penambahan gugus $\mathrm{OH}$ pada adsorben $\left(\mathrm{A}_{2}\right)$, sedangkan dengan BET menunjukkan adsorben $\mathrm{A}_{2}$ mengalami penurunan luas permukaan dan total volume pori sebesar $39,83 \%$ dan $21,89 \%$, sedangkan rata-rata ukuran pori mengalami kenaikan sebesar 29,54\%. Kemampuan adsorben $A_{1}$ maupun $A_{2}$ terhadap penyerapan campuran ion logam tembaga dan kromium waktu kontak terbaik adalah 120 dan 90 menit dengan konsentrasi terbaik (1:1) sama yaitu $30 \mathrm{ppm}$. Kapasitas adsorpsi maksimum oleh adsorben $\mathrm{A}_{1}$ maupun $\mathrm{A}_{2}$ untuk ion logam tembaga sebesar $2,02.10^{-3} \mathrm{~mol} \mathrm{~g}^{-1}$ dan $2,49.10^{-3} \mathrm{~mol} \mathrm{~g}^{-1}$, sedangkan untuk ion logam kromium sebesar $1,49 \cdot 10^{-3} \mathrm{~mol} \mathrm{~g}^{-1}$ dan $1,63.10^{-3} \mathrm{~mol} \mathrm{~g}^{-1}$. 


\section{Daftar Pustaka}

[1] Corie Indria Prasasti, J Mukono, Sudarmaji Sudarmaji, Toksikologi Logam Berat B3 dan Dampaknya terhadap Kesehatan, Jurnal Kesehatan Lingkungan Unair, 2, 2, (2006)

[2] R Ramya, P Sankar, S Anbalagan, PN Sudha, Adsorption of $\mathrm{Cu}$ (II) and Ni (II) ions from metal solution using crosslinked chitosan-g-acrylonitrile copolymer, International journal of environmental sciences, 1, 6, (2011) 1323

[3] Shamik Chowdhury, Papita Das Saha, Biosorption of methylene blue from aqueous solutions by a waste biomaterial: hen feathers, Applied Water Science, 2, 3, (2012) 209-219 http://dx.doi.org/10.1007/s13201012-0039-0

[4] R. Leyva-Ramos, L. E. Landin-Rodriguez, S. LeyvaRamos, N. A. Medellin-Castillo, Modification of corncob with citric acid to enhance its capacity for adsorbing cadmium(II) from water solution, Chemical Engineering Journal, 180, (2012) 113-120 http://dx.doi.org/10.1016/j.cej.2011.11.021

[5] Klaus J Lorenz, Karel Kulp, Handbook of cereal science and technology, Marcel Dekker, New York, 1991.

[6] N Elfia, W Suciati, M Nugroho, Pengaruh Penggunaan Tepung Bulu dan Papain dalam Pakan Ayam Broiller, Laporan Penelitian, Jurusan Ilmu Ternak Universitas Brawijaya, Malang, (2002)

[7] Ismael Alejandro Aguayo-Villarreal, Adrián BonillaPetriciolet, Virginia Hernández-Montoya, Miguel A. Montes-Morán, Hilda E. Reynel-Avila, Batch and column studies of $\mathrm{Zn} 2+$ removal from aqueous solution using chicken feathers as sorbents, Chemical Engineering Journal, 167, 1, (2011) 67-76 http://dx.doi.org/10.1016/j.cej.2010.11.107

[8] Robert Milton Silverstein, G. Clayton Bassler, Terence C. Morrill, Spectrometric Identification of Organic Compounds, 4 ed., Wiley, 1981.

[9] Hardjono Sastrohamidjojo, Spektroskopi, Yogyakarta: Liberty, (1991)

[10] Paul N Cheremisinoff, Fred Ellerbusch, Carbon adsorption handbook, Ann Arbor Science Publishers, 1978.

[11] SM Khopkar, Analitik, Konsep Dasar Kimia, UI Press, Jakarta, 1990.

[12] PW Atkins, Kimia Fisika jilid II. Kartohadiprodjo II, penerjemah; Rohhadyan $\mathrm{T}$, editor, in, Oxford: Oxford University Press. Terjemahan dari: Physical Chemistry, 1999.

[13] Oscik, Adsorption, First Edition ed., Ellis Horwood Limited, England, 1982.

[14] AW Adamson, Physical chemistry of surfaces, John willey and sons Inc, New York, (1990)

[15] dyah Purwaningsih, Interaksi Cr (III) dan Cr (VI) dengan gugus etilendiamin yang terimobilisasi pada silika melalui proses Sol-Gel, Departemen Kimia, Universitas Gadjah Mada, Yogyakarta

[16] Kazuo Nakamoto, Infrared and Raman Spectra of Inorganic and Coordination Compound, Third Edition ed., John Wiley and Sons Inc, New York, 1978.
[17] Enrique J Baran, Structural data and vibrational spectra of the copper (II) complex of $\mathrm{L}$ selenomethionine, Zeitschrift für Naturforschung $B$, 60, 6, (2005) 663-666 http://dx.doi.org/10.1515/znb-2005-0609 